\title{
A new approach to classify wood pruning residues for energy purposes
}

\author{
Letícia Costa Peres ${ }^{\star}$ Angélica de Cássia Oliveira Carneiro, Clarissa Gusmão Figueiró, Lucas de Freitas \\ Fialho, Carlos Miguel Simões da Silva, Antônio Policarpo Souza Carneiro
}

Universidade Federal de Viçosa (UFV), Viçosa, Minas Gerais, Brasil.

\begin{abstract}
The utilization of urban pruning residues for energy production is a sustainable alternative for management of cities. However, the high heterogeneity of these materials is a harmful aspect for its energetic use. Thus, an optimized method is necessary to categorize these residues by similarity, taking the most advantage of the desirable energetic properties of each group. The aim of this study was applying the principal component analysis as a method of pruning residues classification for its energetic use optimization. The structural and proximate chemical composition, basic density, higher heating value, energy density of four pruning residues was determined. Posteriorly, the residues were separated in groups according these characteristics. To generate energy in the most efficient way, the residues were grouped, being group 1 (R2), group 2 (R1) and group 3 (R3 and R4). Groups 1 and 2 are considered more suitable for direct burning, and group 3 for pyrolysis. This process is justified by the increase of the residues value, as the charcoal could be sold to different purposes than the wood, such as the steel industry.
\end{abstract}

Keywords: biomass; proximate analysis; heating value; principal component analysis.

\section{Introduction}

The world is currently dependable of fossil fuels, nonrenewable sources of energy that emitte greenhouse gases. The current rate of consumption of these fuels are concerns for environmental and economic reasons, and a way out of this scenario is the diversification of the energy matrix. Bioenergy corresponds to approximately $10 \%$ of global energy supply, and only one third of this energy use is for industry purposes (VAKKILAINEN et al., 2013).

Biomass is a highly accepted renewable energy source, since it is considered carbon neutral, and it is flexible in a way that can be adapted to be integrated as a complementary or main fuel in existing energy generating systems, such as a simultaneous combustion of the biomass with another fuel source, such as coal and/or natural gas in a boiler to generate electricity. This way, the use of biomass can contribute to diminish the emission of greenhouse gasses (BACHA et al., 2016). An available source of biomass that is mostly unused is pruning residues, whose most common destination are landfills, where they can cause several environmental problems, increasing the risk of fire, degrading the landscape, the air and the water. This present management causes the waste of potential energy materials (JESUS, et al., 2017; PICCHHI, et al., 2018).

In Brazil, the solid waste management plans (MMA, 2012) encourages the reuse of pruning residues as an income generating initiative and encourage the implementation of initiatives for the use of trunks removed from the urban area. Urban forestry, in Brazil, is performed with species that are astatically pleasing, with the aim to improve the cities environment. However, this native species may have multiple 
potential uses, being necessary to knowledge their technological potential (COSTA et al., 2014).

Wood urban pruning residues may have the prospective to be used energetically to produce heat, steam or electricity (MOULING et al., 2017). To better comprehend the more suitable use of each biomass, usually the physical and chemical proprieties of the materials are analyzed and compared. Materials combined without criteria could result in several losses for the energy systems, harming the efficiency of woods with better proprieties by combining then with ones with undesirable characteristics.

Thus, the principal component analysis could be an interesting statistical approach to understand the variance between the tree urban residues and the suitable use. Then, the cluster analyzes can be used to forms groups with most similar residues. Considering that pruning residues are available source of biomass, currently unused, and with potential for energy production.

The use of principal component analysis and cluster analysis as a classification method is a consolidated approach in several scientific areas (genetics, ecology, soil quality, plant pathology, image classification, etc). However, there is no evidence in the literature of studies using this technique in the optimal separation of pruning residues according to its favorable energetic properties. So, the aim of this study is apply principal component analysis as a way to classify pruning residues energetically, providing the most efficient combination and taking the most advantage of their proprieties.

\section{Material and Methods}

The pruning residues used in this study were collected in Viçosa, Minas Gerais state, Brazil. The trees were collected from major pruning and strategic thinning performed by the public company responsible for the area, and those trees that fell by natural causes. The local urban forest is composed by native and exotic trees in the streets and main areas, and by native forest fragments. The composed sample was made from trunk and branches. The pruning residues were collected and classified according to their density (Table 1).

Table 1. Botanical classification of the wood pruning residues.

Tabela 1. Classificação botânica das madeiras resíduos de poda.

\begin{tabular}{cc}
\hline Residue & Botanical classification \\
\hline R1 & Handroanthus $\mathrm{sp}$. \\
R2 & Mimosa sp. \\
R3 & Mimosa scabrella Benth. \\
R4 & Piptadenia gonoacantha (Mart.) J. F. Macbr \\
\hline
\end{tabular}

In order to characterize the residues potential as energetic biomass, several analyzes were made. The wood's basic density was determined according to Vital (1984). To define the other proprieties, the wood was grounded and sifted through a 40 mesh and collected in a 60 mesh sieve. For the proximate analysis, the volatile matter and ash contents were determined according to NBR 8112 (ABNT, 1986), and fixed carbon was obtained by a $100 \%$ difference.

The wood extractives, insoluble lignin content and soluble lignin content were determined according to Soares et al. (2014). The total lignin content was obtained from the sum of insoluble and soluble lignin. The holocelluloses content was determinate by subtracting the contents of lignin, extractives and ashes of a $100 \%$ total. The higher heating value (HHV) was defined according to the methodology in NBR 8633 (ABNT, 1984) in IKA300 calorimeter. The energy density was obtained multiplying the basic density and the higher heating value.

The proprieties mean and coefficient of variance were calculated, then extractives, lignin, basic density and HHV were processed with principal component analyses and the components with eigenvalue major than one were selected. 
These proprieties were chosen in order to avoid multicollinearity. The residues were grouped by similarity, through cluster analysis by complete linkage algorithm. The groups were evaluated to determine which would perform better for direct combustion and which has characteristics to indicate they would perform better as charcoal.

The selected groups from the cluster analysis, that were considered potential for charcoal production according to their properties, were carbonized in an electric muffle oven, in a metallic cylindrical container made of stainless steel with approximately $0.003 \mathrm{~m}^{3}$. The initial temperature was $100{ }^{\circ} \mathrm{C}$ and final $450{ }^{\circ} \mathrm{C}$, for 4.5 hours, increasing the temperature by $50{ }^{\circ} \mathrm{C}$ every 30 minutes, and remaining in the final temperature for an hour, with a heating rate of $1.67^{\circ} \mathrm{C} \mathrm{min}^{-1}$. The yield was determined according to the mass of wood before the pyrolysis and charcoal after, by gravimetry.

Charcoal friability was evaluated trough a friability analyzer, the samples with known mass rotated for 17 minutes in $35 \mathrm{rpm}$, they were dusted and weighted, and the percentage of mass lost calculated (Eq. 1).

$$
\operatorname{Friability}(\%)=\left(\frac{W_{i}-W_{f}}{W_{i}}\right) \quad(\text { Equation 1) }
$$

Where: $\mathrm{Wi}=$ Initial weight; $\mathrm{Wf}=$ Final weight.

The apparent relative density was determined though immersion in mercury, according to the hydrostatic method (VITAL, 1984). The charcoal's proximate analysis, volatile matter and ash content, were measured according to NBR 8112 (ABNT, 1986), and the fixed carbon content was obtained by a $100 \%$ difference. Higher heating value (HHV) was measured according to NBR 8633 (ABNT, 1984) in IKA300 calorimeter. The energy density is the product of the apparent relative density and HHV.

\section{Results and Discussion}

The characteristics of the residues vary substantially, as it can be observed in Table 2. The residues from this study differ considerably in holocelluloses content (67.06 to $48.45 \%$ ), but not as much in volatile matter content (87.19 to $80.91 \%)$. The ones that presented the major amount of holocellulose also presented the major volatile matter.

Table 2. Mean and coefficient of variation for wood proprieties of the residues

Tabela 2. Média e coeficiente de variação para propriedades da madeira dos resíduos

\begin{tabular}{|c|c|c|c|c|}
\hline & R1 & R2 & R3 & R4 \\
\hline \multirow{2}{*}{$\begin{array}{c}\text { Extractives } \\
(\%)\end{array}$} & 6.79 & 6.75 & 4.38 & 4.00 \\
\hline & (4.68) & (1.17) & $(0.49)$ & $(0.37)$ \\
\hline \multirow{2}{*}{ Lignin (\%) } & 34.09 & 26.38 & 47.16 & 28.49 \\
\hline & $(0.84)$ & (4.63) & (1.28) & $(0.84)$ \\
\hline Holocellulose & 58.12 & 65.49 & 48.45 & 67.06 \\
\hline$(\%)$ & (1.04) & (1.99) & (1.29) & $(0.34)$ \\
\hline \multirow{2}{*}{ Ash (\%) } & 1.00 & 1.39 & 0.59 & 0.45 \\
\hline & (8.56) & (8.39) & (5.19) & (5.11) \\
\hline Volatile & 85.44 & 81.27 & 80.91 & 87.19 \\
\hline matter (\%) & (1.15) & (1.50) & $(0.29)$ & (1.36) \\
\hline Fixed carbon & 13.56 & 17.34 & 18.50 & 12.36 \\
\hline$(\%)$ & (7.38) & (7.28) & (1.41) & (9.74) \\
\hline Basic density & 0.70 & 0.57 & 0.55 & 0.53 \\
\hline$\left(\mathrm{g} \mathrm{cm}^{-3}\right)$ & (1.43) & $(4.02)$ & (2.19) & (3.79) \\
\hline $\begin{array}{c}\text { Higher } \\
\text { Heating Value }\end{array}$ & 20.02 & 19.56 & 19.73 & 19.82 \\
\hline$\left(\mathrm{MJ} \mathrm{Kg}^{-1}\right)$ & $(0.09)$ & $(0.65)$ & $(0.28)$ & $(0.72)$ \\
\hline Energy & & & & \\
\hline $\begin{array}{l}\text { Density } \\
\left(\mathrm{GJ} \mathrm{m}^{-3}\right)\end{array}$ & 14.01 & 11.15 & 10.85 & 10.50 \\
\hline
\end{tabular}

Holocelluloses, whose degradation in the main responsible for the release of volatile matter, is important for the use of wood as a fuel, contributing to the ignition and combustion of the woody materials (HAYKIRI-ACMA et al., 2010; DA SILVA et al., 2016). Lignin has higher resistance to thermal degradation when compared to the other main components of wood, manly since it has various aromatic rings, with a wide range of different chemical bonds causing the degradation to happen in a wide temperature range. Among the main components, lignin is the most difficult one 
to decompose (YANG et al., 2007; VEIGA et al., 2017). This causes the longer residence time, and the longer refueling time.

Lignin is the main component responsible for the fixed carbon content, however, can be noted that the extractives can also contribute (ZANUNCIO et al., 2014; MOULING et al., 2017; SOLAR et al., 2017). An example is residue R2, which has the lowest lignin content and a relatively high fixed carbon content, due to the higher extractive content. Extractives can contribute to the use of the wood as a fuel, for example increasing the higher heating value, depending on its chemical composition, that can vary greatly among different wood materials. Regarding the ash, it does not generate energy and can cause several problems to equipment, as well and requiring proper disposal (CARNEIRO et al., 2016).

Higher heating value determines how concentrated energy is, influencing the residues use as a fuel. Its related to several characteristics of the wood, as the anatomical proprieties and the content of each major wood component. It is possible to notice, for example, that $\mathrm{R} 2$ has the lowest $\mathrm{HHV}$, consequence of the highest ash content (COUTO et al., 2013). Energy density is the combination of the HHV and basic density, meaning that less dense residues would require a larger amount than denser ones, to generate the same amount of energy. That can be observed with R4, that has the second highest HHV but the lowest energy density, due to the basic density value.

In table 3, the results of standard deviation, proportion of variance and cumulative proportion from the principal component analyses are presented. In Principal Component Analysis, the number of components chosen to explain the data, should be determined to better represent the data base, with the risk of not being representative. There are two issues that could be caused by the poorly represented data. The first one is the uncertainty that the data could be generalized, only representing a specific sample. The second is the component being monopolized by one variable, therefore not representing the other variables (CUADROS-RODRÍGUEZ et al., 2016).

Table 3. Eigenvalue, variance and cumulative variance of the principal component analysis (PC).

Tabela 3. Autovalor, variância e variância cumulativa da análise de componentes principais (PC).

\begin{tabular}{c|cccc}
\hline & PC1 & PC 2 & PC 3 & PC 4 \\
\hline Eigenvalue & 1.43 & 1.16 & 0.78 & 0.05 \\
Variance & 0.51 & 0.34 & 0.15 & 0.00 \\
Cumulative variance & 0.51 & 0.85 & 1.00 & 1.00 \\
\hline
\end{tabular}

The components with eigenvalue major than one were selected, as they explained $84.7 \%$ of data variability. In table 4 , the eigenvectors from each variable is presented. There were no variables with high correlation in component 1 , though basic density is the main responsible for $68.9 \%$ of data variation in the first principle component. Thus, lignin is the main responsible for $70.6 \%$ of data variation in the second principle component.

Table 4. Eigenvectors from wood properties in chosen components.

Tabela 4. Autovetores das propriedades da madeira das componentes escolhidas.

\begin{tabular}{|c|c|c|}
\hline & $\begin{array}{c}\text { Principal } \\
\text { Component } 1\end{array}$ & $\begin{array}{c}\text { Principal } \\
\text { Component } 2\end{array}$ \\
\hline Extractives & 0.550 & -0.433 \\
\hline Lignin & -0.141 & 0.706 \\
\hline $\mathrm{HHV}$ & 0.451 & 0.545 \\
\hline Basic density & 0.689 & 0.134 \\
\hline
\end{tabular}

To better observe the principal components, a biplot graphic was made (Figure 1), so the interference of each variable and its relation can be displayed, and the correlation between variables can be stablish. The angles minor to 90 degrees indicate positive correlation and the ones major to 90 degrees a negative correlation. 


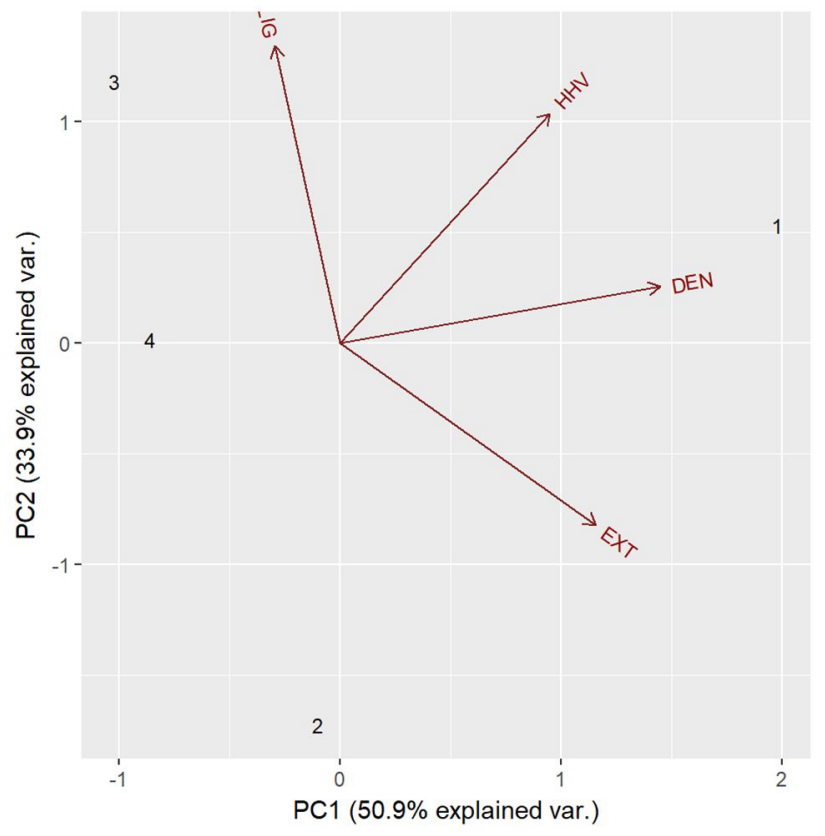

LIG = Lignin content (\%), HHV = higher heating value $\mathrm{MJ}$ $\mathrm{Kg}^{-1}, \mathrm{DEN}=$ Basic density $\mathrm{g} \mathrm{cm}^{-3}, \mathrm{EXT}=$ Total extractives content (\%)

Figure 1. Biplot of principal components 1 (PC1) and 2 (PC2), variable vectors and samples dispersion.

Figura 1. Biplot dos componentes principais 1 (PC1) e 2 (PC2), vetores variáveis e dispersão de amostras.

Higher heating value (HHV) presents a positive correlation with lignin and basic density, presenting an angle less than 90 degrees. These proprieties allow, respectively, that more energy is released and with smaller amounts of material.

The residues were grouped according to the variables and its eigenvalues, forming a dendrogram to better visualize the similarities as presented in Figure 2. Three groups were formed, the mean value of analyzed proprieties from each group is presented in Table 4. Group A is formed by R2, Group B by R1 and Group C by R3 and R4.

The mean values for each group proprieties are presented in Table 5. Group A has the greater amount of holocellulose, and the lowest lignin content; Group B has the greatest HHV and basic density, and the higher amount of volatile matter, which provides characteristics for these residues be considered suitable for direct combustion. Group C has the lowest energy density, but the highest lignin content and an appropriate basic density value to be considered for conversion to charcoal. A minimum of $28 \%$ of lignin content; and basic density major then $0.5 \mathrm{~g} \mathrm{~cm}^{-3}$ is recommended for charcoal production (PEREIRA et al., 2012; PEREIRA et al., 2016).

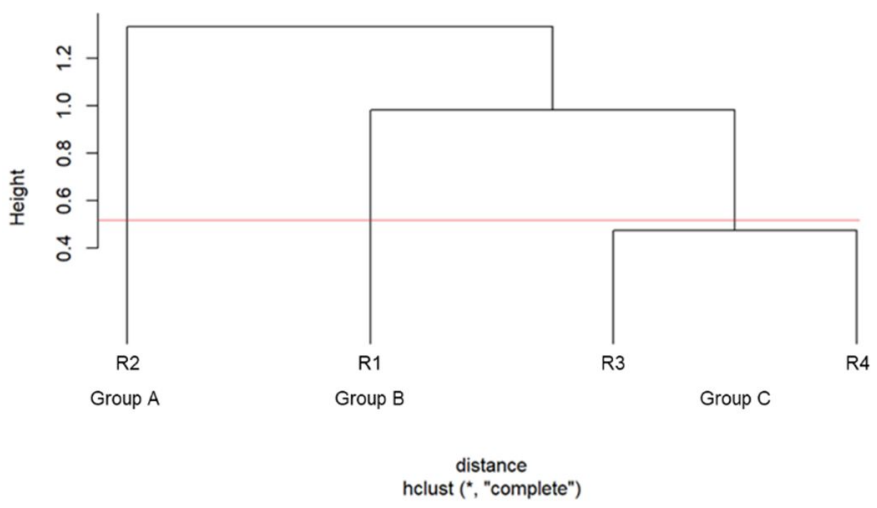

Figure 2. Cluster analysis obtained through "complete linkage".

Figura 2. Análise de cluster obtida por meio de "linkage completo".

Table 5. Means of the grouped residue's properties.

Tabela 5. Médias das propriedades de resíduos agrupadas.

\begin{tabular}{c|ccc}
\hline & Group A & Group B & Group C \\
\hline Extractives (\%) & 6.75 & 6.79 & 4.19 \\
Lignin (\%) & 26.38 & 34.09 & 37.83 \\
Holocellulose (\%) & 65.49 & 58.12 & 57.76 \\
Ash (\%) & 1.39 & 1.00 & 0.52 \\
Volatile matter (\%) & 81.27 & 85.44 & 84.05 \\
Fixed Carbon (\%) & 17.34 & 13.56 & 15.43 \\
Basic density & 0.57 & 0.70 & 0.54 \\
$\quad\left(\right.$ g cm $^{-3}$ ) & & & \\
Higher Heating & 19.56 & 20.02 & 19.78 \\
Value (MJ Kg $\left.{ }^{-1}\right)$ & & & \\
Energy density & 11.15 & 14.01 & 10.68 \\
$\left(\mathrm{GJ} \mathrm{m}^{-3}\right.$ ) & & & \\
\hline
\end{tabular}

To better analyze the performance of the residues after pyrolysis, residues 3 and 4 were carbonized. The following Table 6 presents the results for each of them. 
Table 6. Charcoal properties mean and coefficient of variation.

Tabela 6. Média e coeficiente de variação das propriedades do carvão vegetal.

\begin{tabular}{ccc}
\hline & R3 & R4 \\
\hline Yield (\%) & $34.58_{(2.43)}$ & $35.00_{(3.27)}$ \\
Friability (\%) & $7.12_{(5.40)}$ & $2.57_{(7.96)}$ \\
Volatile matter (\%) & $23.26_{(0.07)}$ & $27.03_{(0.05)}$ \\
Ash (\%) & $1.75_{(0.24)}$ & $0.90_{(0.04)}$ \\
Fixed Carbon (\%) & $74.99_{(0.02)}$ & $72.07_{(0.02)}$ \\
Density $\left(\mathrm{g} \mathrm{cm}^{-3}\right)$ & $0.37_{(19.02)}$ & $0.36_{(11.03)}$ \\
HHV (MJ Kg $\left.)^{-1}\right)$ & $31.39_{(1.84)}$ & $29.97_{(1.05)}$ \\
Energy density $\left(\mathrm{GJ} \mathrm{m}^{-3}\right)$ & $11.61^{2}$ & $10.79^{2}$ \\
\hline
\end{tabular}

After pyrolysis, the values for Group C of yield, ash and fixed carbon content, friability and density are within of what is considered satisfactory for use (AFONSO et al., 2015). This way, the residues performed better as fuels after pyrolysis, increasing the energy released and decreasing undesirable wood characteristics. The viable uses of the charcoal, based on the presented proprieties, surpass the use as direct fuel to generate energy, as they can also be used in the steel industry. For this purpose, the charcoal should present high yield, fixed carbon content, HHV and density; and low friability and ash content.

In charcoal production, average commercial yield does not exceed $30 \%$, due to the characteristics of the material and the process. As for the proximate analysis, the desirables values for the industry are 75 to $80 \%$ for fixed carbon content and 20 to $25 \%$ for volatile matter content. It is important to emphasize that the characteristics of the charcoal are highly influenced by the process of wood conversion, such as the final temperature (PEREIRA et al., 2012; CARNEIRO et al., 2016).

The charcoal yield is influenced by the wood composition, mainly by the lignin content, and the pyrolysis process, such as time and final temperature. The value presented for these residues are adequate, however the values for fixed carbon content are not between $75-80 \%$, which are most desirable for the steel industry. Therefore, increasing the final temperature of the carbonization should increase the fixed carbon content, decrease the volatile matter content, and turn the charcoal more suitable. Concerning friability and ash content, both are below the values to be considered for steel industry (PEREIRA et al., 2013).

\section{Conclusions}

The pruning residues of this study, to be used to generate energy in the most efficient way, should be grouped in three, being group 1 (R2), group 2 (R1) and group 3 (R3 and R4). Groups 1 and 2 are considered more suitable for direct burning, and group 3 for pyrolysis. This process is justified by the increase of the residues value, as the charcoal could be sold to different purposes than the wood, such as the steel industry.

\section{References}

AFONSO, C.M.I, GONÇALVES, T.A.P; MUÑIZ, G.I.B, MATOS, J.L.M., NISGOSKI, S. Mozambique's charcoals energetic properties of nine native species. Eur. J. Wood Prod, v.73, p.131-133, 2015.

ASSOCIAÇÃO BRASILEIRA DE NORMAS TÉCNICAS (ABNT). NBR 8112: Carvão vegetal: análise imediata, Rio de Janeiro, 1986.

ASSOCIAÇÃO BRASILEIRA DE NORMAS TÉCNICAS (ABNT). NBR 8633: Carvão vegetal: determinação do poder calorífico, Rio de Janeiro, 1984.

BACH, Q.; TRAN, K.; SKREIBERG, Ø. Hydrothermal pretreatment of fresh forest residues: Effects of feedstock predrying. Biomass and Bioenergy, v.85, p.76-83, 2016. CARNEIRO, A.C.O., VITAL, B.R., FREDERICO, P.G.U., FIALHO, L.F., FIGUEIRÓ, C.G., DA SILVA, C.M.S. Effect of genetic materials and the site in charcoal quality of short rotation wood. Floresta, v.46, p.473-480, 2016.

COSTA, T.G.; BIANCHI, M.L.; PROTÁSIO, T.P.; TRUGILHO, P.F.; PEREIRA, A. Wood quality of five species 
from cerrado for production of charcoal. Cerne, v.20, p.3746, 2014.

COUTO, A.M., PROTÁSIO, T.P., TRUGILHO, P.F., NEVES, T.A., SÁ, V.A. Multivariate analysis applied to evaluation of eucalyptus clones for bioenergy production. Cerne, v.19, p.525-533, 2013.

CUADROS-RODRÍGUEZ， L., PÉREZ-CASTAÑO， E., RUIZ-SAMBLÁS, C. Quality performance metrics in multivariate classification methods for qualitative analysis. Trends in Analytical Chemistry, v.80, p.612-624, 2016.

DA SILVA, C.M.S., CARNEIRO, A.C.O., PEREIRA, B.L.C., VITAL, B.R., ALVES, I.C.N., MAGALHAES, M.A. Stability to thermal degradation and chemical composition of woody biomass subjected to the torrefaction process. Eur. J. Wood Prod., v.74, p.845-850, 2016.

HAYKIRI-ACMA, H., YAMAN, S., KUCUKBAYRAK, S. Comparison of the thermal reactivities of isolated lignin and holocellulose during pyrolysis. Fuel Processing Technology, v.91, p.759-764, 2010.

JESUS, M.S.; ROMANI, A.; GENISHEVA, Z.; TEIXEIRA, J.A.; DOMINGUES, L. Integral valorization of vine pruning residue by sequential autohydrolysis stages. Journal of Cleaner Production, v.168, p.74-86, 2017.

MINISTÉRIO DO MEIO AMBIENTE (MMA). Solid Waste Management Plans: Guidance Manual, Brasília. 2012.

MOULING, J.C.; NOBRE, J.R.C.; CASTRO, J.P.; TRUGILHO, P.F.; ARANTES, M.D.C. Effect of extractives and carbonization temperature on Energy characteristics of wood waste in amazon rainforest. Cerne, v.23, p.209-218, 2017.

PEREIRA, B.L.C.; CARVALHO, A.M.M.L.; OLIVEIRA, A.C.; SANTOS, L.C.; CARNEIRO, A.C.O.; DE MAGALHÃES, M.A. Efeito da carbonização da madeira na estrutura anatômica e densidade do carvão vegetal de Eucalyptus. Ciênc. Florest. v.26, n.2, 2016.

PEREIRA, B.L.C., CARNEIRO, A.C.O., CARVALHO, A.M.L., COLODETTE, J. L., OLIVEIRA, A. C., FONTES, M. P. F. Influence of Chemical Composition of Eucalyptus Wood on Gavimetric Yield and Charcoal Proprerties. BioResources, v.8, p.4574-4592, 2013.

PEREIRA, B.L.C., OLIVEIRA, A.C., CARVALHO, A.M.M.L., CARNEIRO, A.C.O., SANTOS, L.C., VITAL, B.R. Quality of
Wood and Charcoal from Eucalyptus Clones for Ironmaster Use. International Journal of Forestry Research, v.2012, p.1-8, 2012.

PICCHHI, G.; LOMBARDINIM C.; PARI, L.; SPINELLI, R. Physical and chemical characteristics of renewable fuel obtained from pruning residues. Journal of Cleaner Production, v.171, p.457-463, 2018.

SOARES, V.C.; BIANCHI, M.L.; TRUGILHO, P.F.; HÖFLER, J.; PEREIRA, A. Análise das propriedades da madeira e do carvão vegetal de híbridos de eucalipto em três idades. Cerne, v.21, p.191-197, 2014.

SOLAR, J., HERNANDEZ, A., LOPEZURIONABARRENECHEA, A., MARCO, I., ADRADOS, A., CABALLERO, B.M., GASTELU, N. From woody biomass waste to biocoke: influence of the proportion of different tree components. Eur. J. Wood Prod. v.75, p.485-497, 2017.

VAKKILAINEN, E.; KUPARINEN, K.; HEINIMÖ, J. Large Industrial Users of Energy Biomass. International Energy Agency, 2013.

VEIGA, T.R.L.A., LIMA, J.T., DESSIMONI, A.L.A., PEGO, M.F.F., Soares, J.R.; Trugilho, P.F. Different plant biomass characterizations for biochar production. Cerne, v.23, p.529-536, 2017.

VITAL, B.R. Methods of determining wood density. Sociedade de Investigações Florestais, Viçosa, 1984.

YANG, H., YAN, R., CHEN, H., LEE, D.H., ZENG, C. Characteristics of hemicellulose, cellulose and lignin pyrolysis. Fuel, v.86, p.1781-1788, 2007.

ZANUNCIO, A.J.V., CARVALHO, A.G., TRUGILHO, P.F., MONTEIRO, T.C. Extractives and energetic properties of wood and charcoal. Revista Árvore, v.38, p.369-374, 2014.

ZWICK, W.R., VELICER, W.F. Factors influencing four rules for determining the number of components to retain. Multivariate Behavioral Research, v.7, p.253-269, 1982. 